\title{
Variation between and within broomrape (Orobanche) species revealed by RAPD markers
}

\author{
ILAN PARAN*, DAVID GIDONI \& REUVEN JACOBSOHN† \\ Department of Genetics and Plant Breeding and †Department of Vegetable Crops, Agricultural Research \\ Organization, The Volcani Center, PO Box 6, Bet Dagan, 50250, Israel
}

\begin{abstract}
The variation among and within natural populations of broomrape (Orobanche) species, a parasitic flowering plant, was determined by using random amplified polymorphic DNA (RAPD) markers. Interspecific variation was determined among five major broomrape species in Israel: $O$. aegyptiaca, $O$. mutelii, $O$. cernua, $O$. cumana and $O$. crenata. The pattern of interspecific variability and genetic distances observed in this study was in agreement with previous taxonomical characterization based on morphological differences among the species. Intraspecific variation was determined for $O$. aegyptiaca and $O$. crenata. Whereas 99 per cent of the amplified fragments were polymorphic among the species, only 23 per cent and 21 per cent, respectively, of the amplified fragments were polymorphic within $O$. aegyptiaca and $O$. crenata. For both species, each individual plant had a unique genotype based on a combined pattern of all the markers. No evidence was obtained for host differentiation for $O$. aegyptiaca and $O$. crenata and for regional differentiation for $O$. crenata.
\end{abstract}

Keywords: broomrape, diversity, RAPD markers.

\section{Introduction}

Broomrape (Orobanche spp.) is an obligate parasite that infects roots of dicotyledonous plants. This parasite causes severe damage to crop plants of many families (summarized by Parker, 1994). The mode of reproduction of the parasite makes its control extremely difficult; it can produce thousands of tiny seeds that are easily dispersed by humans, machinery, animals and wind. The seeds remain viable in the soil for many years and germinate only after stimulation by root exudates of the host. Most broomrape species have a wide host range that includes crop and wild species so that their eradication is almost impossible. Selective chemical control of broomrape by herbicide application is effective in limited cases, only where the crops are sufficiently tolerant to the compounds (Foy et al., 1989). Soil treatments such as fumigation and solarization (Jacobsohn et al., 1980) can be effective for the control of broomrape but are expensive to apply. The best method to control broomrape is breeding for resistance to the pathogen but resistance has been identified in only a few crops such as sunflower

\footnotetext{
*Correspondence. E-mail: vcparan@volcani.agri.gov.il
}

and vetch (Gil et al., 1984; Ish-Shalom et al., 1993).

The centre of the natural distribution of Orobanche is in the Mediterranean region. It is also, however, a common introduced weed in other regions such as eastern Europe, south-west Asia and Western Australia (Musselman, 1986). The genus Orobanche is subdivided into four sections of which the Trionychon and Osproleon sections (also known as section Orobanche) include species that are of economic importance (Pieterse, 1979). The genus includes about 100 species, of which the most important (in terms of damage caused to crop species) are: $O$. ramosa, $O$. aegyptiaca, $O$. cernua, $O$. cumana and $O$. crenata. Orobanche ramosa and $O$. aegyptiaca are included in the section Trionychon. They are morphologically very similar to one another, have similar host ranges, are characterized by a branched flowering stem and have the same chromosome number. Orobanche cernua, $O$. cumana and $O$. crenata belong to the section Osproleon and are characterized by an unbranched stem. Orobanche cernua and $O$. cumana are closely related to each other and were only recently designated as separate species (Joel, 1988). In Israel, O. cumana has a more limited host range than $O$. cernua; it mainly comprises sunflower. The host range of $O$. 
cernua in Israel mostly comprises Solanaceae species (Joel and Jacobsohn, 1988).

Most taxonomical studies of Orobanche have used morphological differences among the species (reviewed by Musselman, 1986). Very little information is available on the genetic variation among and within species based on molecular markers. Verkleij et al. $(1986,1989,1991)$ used isozymes to study the variation in $O$. crenata and in $O$. aegyptiaca in Syria and in Spain. In the present study we used random amplified polymorphic DNA (RAPD) markers to study the variation among and within the major broomrape species in Israel

\section{Materials and methods}

\section{Plant material}

Broomrape plants were collected from naturally infected cultivated crops in several different parts of Israel (Table 1). Interspecific variation was studied among five species: $O$. aegyptiaca, $O$. mutelii (a subspecies of $O$. ramosa; Chater \& Webb, 1972), $O$. cernua, $O$. crenata and $O$. cumana. Intraspecific variation was studied in two species: $O$. aegyptiaca and O. crenata.

\section{DNA isolation and amplification}

Three fresh flowers per plant were used for DNA extraction using the $\mathrm{CTAB}$ method (Doyle \& Doyle, 1990). For the study of interspecific variation, DNA of each species was bulked from five individuals and was used as a template for PCR amplification. For the intraspecific variation study, DNA from individual plants was used as a template for PCR amplification. DNA was amplified by a Perkin-Elmer Cetus thermocycler as described previously (Paran et al., 1991). Ten-mer oligonucleotide primers were purchased from Operon Technologies (Alameda, CA). Amplification products were resolved by electrophoresis, using 1.5 per cent agarose gels, and were photographed after ethidium bromide staining. For all studies, each of the reactions was carried out twice and only bands that were reproducible, i.e. present or absent in both reactions, were included for the analyses.

\section{Data analysis}

Genetic distances (GD) based on pairwise comparisons were calculated by means of Jaccard's formula (1908), using the MEANS procedure of SAS (1988). $\mathrm{GD}=1-n_{\mathrm{xy}} /\left(n_{\mathrm{x}}+n_{\mathrm{y}}-n_{\mathrm{xy}}\right)$ where $n_{\mathrm{xy}}$ is the number of bands common to line $x$ and line $y, n_{x}$ is the total number of bands in line $x$ and $n_{y}$ is the total number of bands in line $y$. Genetic distances were used to construct a dendrogram, using average linkage determined by the CLUSTER procedure of SAS (1988).

\section{Results}

\section{Interspecific variation}

Out of 60 primers (kits A, B and C) that were screened to test their efficiency for amplification of the Orobanche genome, 22 primers (A9, A18, B1, B4, B5, B6, B7, B8, B10, B11, B17, B18, C1, C2, C5,

Table 1 Sampling of Orobanche plants in Israel

\begin{tabular}{lllc}
\hline Species & Collection site & Host & No. of plants \\
\hline O. aegyptiaca $\dagger$ & Golan Heights & Tomato & 5 \\
O. mutelii $\dagger$ & Golan Heights & Tomato & 5 \\
O. cermua $\dagger$ & Golan Heights & Tomato & 5 \\
O. crenata $\dagger$ & Bet Shean & Pea & 5 \\
O. cumana $\dagger$ & Bet Dagan & Sunflower & 5 \\
O. aegyptiaca $\ddagger$ & Bet Dagan & Tomato & 10 \\
& & Eggplant & 10 \\
& & Vetch & 10 \\
& & Faba bean & 10 \\
& & Chickpea & 10 \\
O. cernua $\ddagger$ & Bet Dagan & Faba bean & 12 \\
& & Vetch & 12 \\
& Bet Shean & Carrot & 24 \\
\hline
\end{tabular}

$\nmid$ Indicates samples used for interspecific variation study.

‡Indicates samples used for intraspecific variation study. 
$\mathrm{C} 6, \mathrm{C} 7, \mathrm{C} 10, \mathrm{C} 11, \mathrm{C} 12, \mathrm{C} 13$ and $\mathrm{C} 14)$ gave a robust and reproducible amplification and were selected for further analysis. Polymorphism among the five species was detected with all the 22 primers. A total of 290 different bands was observed for the five species with an average of 13 bands per primer. Only four bands ( 0.01 per cent) were monomorphic for all the five species. Figure 1 is an example of the amplification pattern obtained for the five species. The presence and absence of the amplification products were used to calculate genetic distances among the species (Table 2) and to construct a dendrogram by an average linkage cluster analysis (Fig. 2). The matrix of the genetic distances and the cluster analysis clearly separated the five species into two clusters. The first cluster included $O$. cumana and $O$. cernua $(\mathrm{GD}=0.29)$. The second cluster included $O$. aegyptiaca and $O$. mutelii which were the most closely related $(G D=0.08)$ among the five broomrape species. Orobanche crenata was more closely related to the $O$. cumana and $O$. cernua

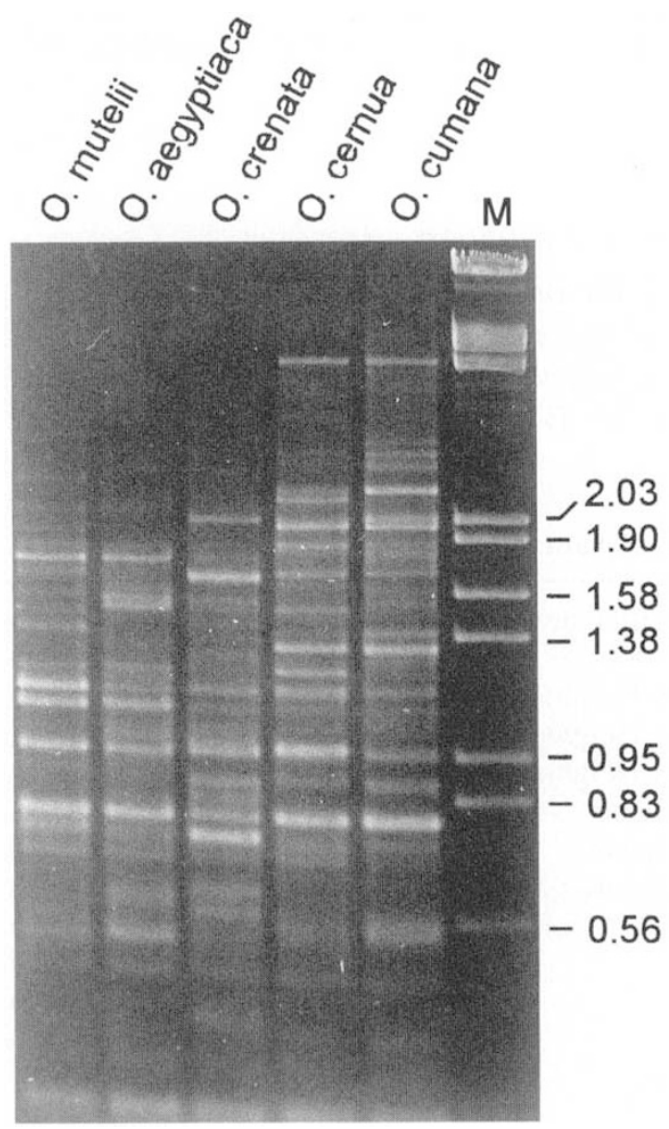

Fig. 1 Amplification patterns obtained from five Orobanche species using primer OPC-05. Last lane contains a lambda Eco RI/HindIII size marker in kbp. cluster $(\mathrm{GD}=0.72)$ than to the $O$. aegyptiaca and $O$. mutelii cluster $(\mathrm{GD}=0.90)$.

\section{Intraspecific variation}

Twenty primers (A1, A2, A3, A4, B1, B7, B8, B10, $\mathrm{B} 17, \mathrm{~B} 18, \mathrm{C} 1, \mathrm{C} 6, \mathrm{C} 7, \mathrm{C} 8, \mathrm{C} 10, \mathrm{C} 11, \mathrm{C} 13, \mathrm{C} 14, \mathrm{C} 15$ and $\mathrm{C} 16)$ were used to amplify DNA from individual broomrape plants of $O$. aegyptiaca and $O$. crenata (Fig. 3). For both species, the level of intraspecific polymorphism was similar but was considerably lower than the level of interspecific polymorphism. Of the primers, 65 and 75 per cent were polymorphic for $O$. aegyptiaca and $O$. crenata, respectively. Whereas 99 per cent of the amplified fragments were polymorphic among the species, 23 and 21 per cent were polymorpic within $O$. aegyptiaca and $O$. crenata, respectively. Whereas the mean genetic distance among the five species was 0.73 , the mean genetic distances within $O$. aegyptiaca and $O$. crenata were 0.21 and 0.15 , respectively (GD ranged from 0.05 to 0.30 and from 0.06 to 0.26 in $O$. aegyptiaca and $O$. crenata, respectively). Each individual plant within the two species had a unique genotype based on the presence or absence of all bands.

We determined whether individual broomrape plants collected from one host were more closely related to one another than to broomrape plants of the same species collected from different hosts in the same collection region. For each host of $O$.

Table 2 Genetic distances among five Orobanche species calculated from the presence and absence of the amplification products of 22 RAPD primers

\begin{tabular}{lcccc}
\hline & $\mathrm{P}_{1}$ & $\mathrm{P}_{2}$ & $\mathrm{P}_{3}$ & $\mathrm{P}_{4}$ \\
\hline $\mathrm{P}_{2}$ & 0.29 & & & \\
$\mathrm{P}_{3}$ & 0.93 & 0.92 & & \\
$\mathrm{P}_{4}$ & 0.92 & 0.91 & 0.08 & \\
$\mathrm{P}_{5}$ & 0.76 & 0.72 & 0.89 & 0.91 \\
\hline
\end{tabular}

$\mathrm{P}_{1}$, O. cumana; $\mathrm{P}_{2}$, O. cernua $; \mathrm{P}_{3}, O$ aegyptiaca $; \mathrm{P}_{4}, O$. mutelii; $\mathrm{P}_{5}, O$. crenata.

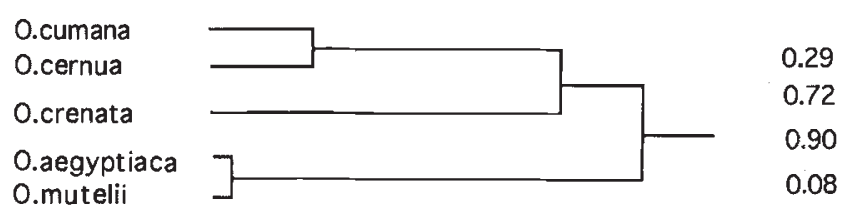

Fig. 2 A dendrogram of five Orobanche species based on average linkage cluster analysis using RAPD markers. Genetic distances between the species are indicated on the right of the dendrogram.

(c) The Genetical Society of Great Britain, Heredity, 78, 68-74. 
(a)

$123 \quad 3 \quad 4 \quad 5 \quad 6 \quad 7 \quad 891011121314151617181920212223 \mathrm{M}$

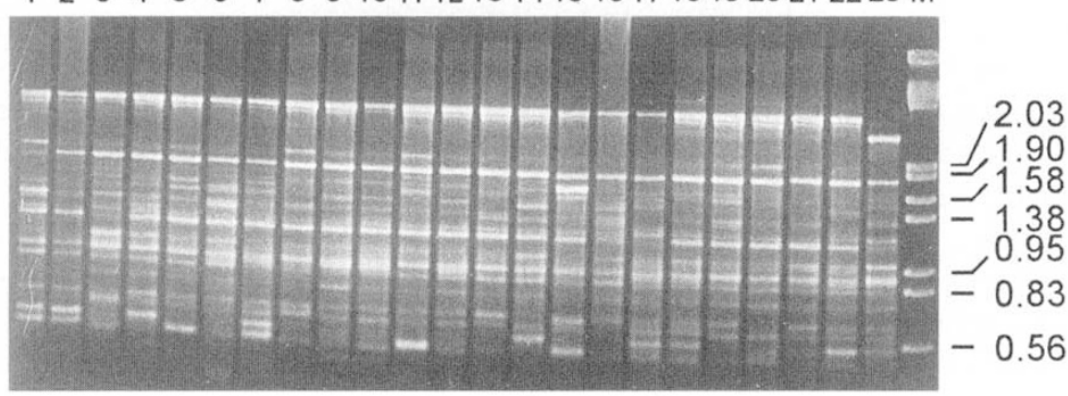

(b)

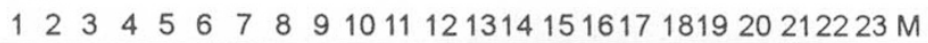

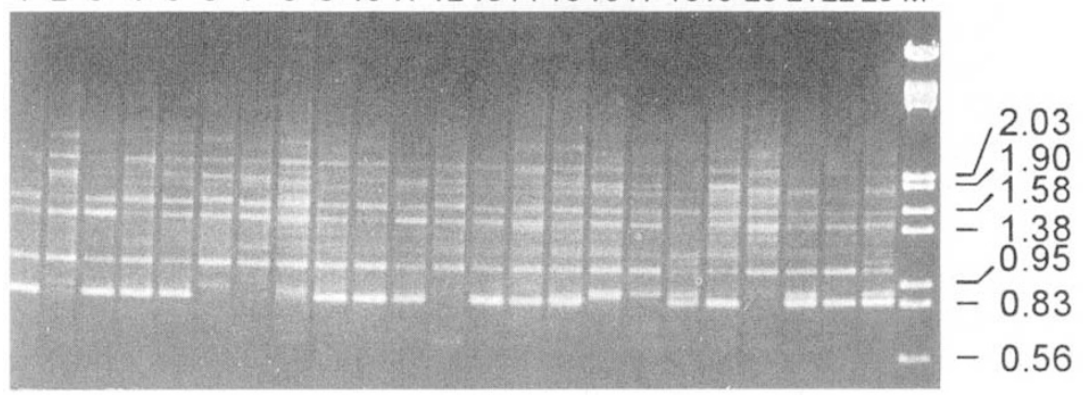

Fig. 3 Amplification patterns obtained from individual plants of two Orobanche species using primer OPC-13. (a) Lanes 1-10, 11-20, 21-23: $O$. aegyptiaca collected from eggplant, tomato and vetch, respectively. (b) Lanes 1-12, 13-23: $O$. crenata collected from vetch in Bet Dagan and from carrot in Bet Shean, respectively. Last lane contains a lambda Eco RI/HindIII size marker in kbp. crenata and $O$. aegyptiaca, the mean GD among plants within a host was calculated from pairwise comparison of all plants collected from the same host. Mean GDs between hosts were calculated from pairwise comparison of each of the plants in one host with each of the plants from all the other hosts.

For both species, there was no difference in the mean GD between plants within hosts $(\mathrm{GD}=0.21$ and $\mathrm{GD}=0.15$ for $O$. aegyptiaca and $O$. crenata, respectively) and between plants collected from different hosts $(\mathrm{GD}=0.23$ and $\mathrm{GD}=0.17$ for $O$. aegyptiaca and $O$. crenata, respectively, Table 3 ). Similarly, there was no difference in the mean GD among $O$. crenata plants collected within regions $(G D=0.15$ and $G D=0.16$ in Bet Dagan and Bet Shean, respectively) and the mean GD between the two regions $(\mathrm{GD}=0.17$, Table 3$)$. These results, although based on a relatively small sample, indicate that most if not all of the intraspecific variation in the two Orobanche species in Israel is among individuals and not among hosts nor between regions.

\section{Discussion}

This is the first report on the use of DNA markers for the study of variation in natural Orobanche
Table 3 Mean genetic distances among plants of two Orobanche species calculated from the presence and absence of the amplification products of 20 RAPD primers

a. Mean genetic distances among $O$. aegyptiaca plants within and between hosts.

\begin{tabular}{lccccc}
\hline & $\mathrm{H}_{1}$ & $\mathrm{H}_{2}$ & $\mathrm{H}_{3}$ & $\mathrm{H}_{4}$ & $\mathrm{H}_{5}$ \\
\hline $\mathrm{H}_{1}$ & 0.17 & & & & \\
$\mathrm{H}_{2}$ & 0.19 & 0.21 & & & \\
$\mathrm{H}_{3}$ & 0.20 & 0.21 & 0.22 & & \\
$\mathrm{H}_{4}$ & 0.20 & 0.21 & 0.21 & 0.21 & \\
$\mathrm{H}_{5}$ & 0.22 & 0.24 & 0.24 & 0.23 & 0.27 \\
\hline
\end{tabular}

$H_{1}$, eggplant; $H_{2}$, vetch; $H_{3}$, tomato; $H_{4}$, chickpea; $H_{5}$, faba bean.

b. Mean genetic distances among $O$. crenata plants within and between hosts and between regions

\begin{tabular}{llll}
\hline & $\mathrm{H}_{1}$ & $\mathrm{H}_{2}$ & $\mathrm{H}_{3}$ \\
\hline $\mathrm{H}_{1}$ & 0.13 & & \\
$\mathrm{H}_{2}$ & 0.16 & 0.17 & \\
$\mathrm{H}_{3}$ & 0.17 & 0.17 & 0.16 \\
\hline
\end{tabular}

$\mathrm{H}_{1}$, faba bean, Bet Dagan; $\mathrm{H}_{2}$, vetch, Bet Dagan; $\mathrm{H}_{3}$, carrot, Bet Shean. 
populations. The pattern of the interspecific variation which was revealed in the present study is in agreement with earlier taxonomical studies of Orobanche (Musselman, 1986). The partition of the five species into two different sections according to the previous taxonomic work is well apparent in the present study as the greatest genetic distances were among species from different sections.

The most closely related speceis were $O$. aegyptiaca and $O$. mutelii in section Trionychon $(\mathrm{GD}=0.08)$. Orobanche mutelii is considered as a subspecies of $O$. ramosa and it is characterized by a smaller corolla than $O$. aegyptiaca. In section Osproleon, $O$. cernua and $O$. cumana were more closely related to each other $(\mathrm{GD}=0.29)$ and to $O$. crenata (GD $=0.72$ and 0.76 between $O$. crenata and $O$. cernua and between $O$. crenata and $O$. cumana, respectively). Orobanche cumana has often been considered as a subspecies of $O$. cernua, but Joel (1987) and Jacobsohn et al. (1991) clearly differentiated between the two species on the basis of morphological and host range differences.

The present study indicated that all the diversity detected within populations of $O$. aegyptiaca and $O$. crenata in Israel is among individuals and not among hosts. Therefore, no evidence for host differentiation was obtained. Musselman (1986) suggested that the host of a parasitic plant such as Orobanche may play a role in the variability of the parasite. Some evidence for such a role was indicated by Musselman \& Parker (1982) as plants collected from one host and grown on a second differed from each other in their morphology. Indications for differentiation of Orobanche populations of several species, in particular with regard to differences in degree of virulence, were summarized by Verkleij \& Pieterse (1994). Differences in the level of aggressiveness among populations were detected for example for $O$. cernua on sunflower and for $O$. crenata on faba bean.

Just as there was no influence of the host on RAPD variability in Orobanche, so regional differences had no influence on the diversity of $O$. crenata populations. The average genetic distance among plants from Bet Dagan and Bet Shean (the two regions are $150 \mathrm{~km}$ apart) was 0.17 compared with 0.15 and 0.16 among plants within Bet Dagan and Bet Shean, respectively. The lack of divergence between the two populations may indicate that there is little differentiation of $O$. crenata populations in Israel, which may be explained by gene flow between the populations. Such gene flow may be a result of extremely efficient dispersal of the parasitic seeds. Similar results were obtained by Verkleij et al. (1989) for two O. crenata populations in Syria. These authors measured allozyme variation in two populations that were collected in sites $125 \mathrm{~km}$ apart. Although a high level of variation was detected within the populations, the detected variation was entirely at the intrapopulation level. Slightly more interpopulation variation ( 4 per cent of the total variation) was detected among $O$. crenata populations in Spain (Verkleij et al., 1991). The largest genetic distance found between populations was between the Syrian and Spanish ones (Verkleij \& Pieterse, 1994). The partition of RAPD variation between close and remote regions for another allogamous species, buffalo grass, was carried out by Huff et al. (1993) who found that the largest fraction (58 per cent) of the genetic differences was between remote regions (Texas vs. Mexico), whereas only 10 per cent of the variation was between local populations.

In the present study, although the level of intraspecific variation in the two species was much lower than that of interspecific variation, there was a considerable variation among individual broomrape plants within each species, and each of the plants in the entire data set was genetically unique. These results are similar to previous studies in which a high degree of allozyme variation was detected within $O$. aegyptiaca and $O$. crenata populations (Verkleij et al., 1986, 1989). Both O. aegyptiaca and $O$. crenata are considered to be allogamous species. The degree of variability among broomrape individuals was similar to that found in other investigations in which the partition of variation for allogamous species was studied by means of RAPD markers. For tea (Wachira et al., 1995), 70 per cent of the intraspecific variation was within populations and 30 per cent between populations. Similarly, the majority of RAPD variation in Eucalyptus and in buffalo grass (74-95 per cent and 73-80 per cent of the total variation in Eucalyptus and buffalo grass, respectively) was found to be within rather than between populations (Huff et al., 1993; Nesbitt $e t$ al., 1995). These levels of intrapopulation variation were higher than that for inbreeding species such as Hordeum spontaneum and Gliricidia sepium (Chalmers et al., 1992; Dawson et al., 1993).

In the present study, RAPD markers have been demonstrated to be a useful tool for studies of variation in the genus Orobanche. Further studies could utilize RAPD markers to address several basic as well as practical issues concerning variation in the genus. These include: the partition of variation within and between populations in additional species, the partition of variation between populations as a function of geographical distance between 
the regions of collection and the partition of variation between populations that differ in their virulence. In addition to the five Orobanche spp. that were included in the present study, there are numerous additional species that are pathogens to the wild flora in Israel. The relatedness among the wild species and the species attacking crop plants needs to be determined. As broomrape plants are largely allogamous, there is a possibility for interspecific crosses and as a consequence a possible change in host range. RAPD markers could be used to monitor gene flow between the species in case of such changes.

\section{Acknowledgements}

We thank A. Gnizi and A. Beiles for assistance with statistical analyses and helpful discussions. This work was supported by grant HNE-0158-G-00-3060-00 of The International USA-Egypt-Israel program of the US Agency for International Development (AID), and a contribution from the Agricultural Research Organization, The Volcani Center, Bet Dagan, Israel. No. 1759-E, 1995 series.

\section{References}

CHALMERS, K. S., WAUGh, R., SPENT, J. I, Simons, A. J. AND POWELL, w. 1992. Detection of genetic variation between and within populations of Gliricidia sepium and G. maculata using RAPD markers. Heredity, 69, 465-472.

CHATER, A. O. AND WEBB, D. A. 1972. Orobanche. In: Tutin, T. G., Heywood, V. H., Burgess, N. A., Walters, S. M. and Webb, D. A. (eds) Flora Europaea, vol. 3, pp. 286-393. Cambridge University Press, Cambridge.

DAWSON, I. K., CHALMERS, K. J., WAUGH, R. AND POWELL, W. 1993. Detection and analysis of genetic variation in Hordeum spontaneum populations from Israel using RAPD markers. Mol. Ecol., 2, 151-159.

DOYLE, J. J. AND DOYLE, J. L. 1990. Isolation of plant DNA from fresh tissue. Focus, 12, 13-14.

FOY, C. L., JAIN, R. AND JACOBSOHN, R. 1989. Recent approaches for chemical control of broomrape. Rev. Weed Sci., 4, 123-152.

GIL, J., MARTIN, L. M. AND CUBERO, J. I. 1984. Resistance to Orobanche crenata Forssk. in Vicia sativa L. II. Characterization and genetics. In: Parker, C., Musselman, L. J. and Polhill, R. M. (eds) Third International Symposium on Parasitic Weeds, Aleppo, Syria, pp. 221-229.

HUFF, D. R., PEAKALL, R. AND SMOUSE, P. E. 1993. RAPD variation within and among natural populations of outcrossing buffalograss [Buchloe dactyloides (Nutt.) Engelm.]. Theor. Appl. Genet., 86, 927-934.

ISH-SHALOM-GORDON, N., JACOBSOHN, R. AND COHEN, Y. 1993. Inheritance of resistance to Orobanche cumana in sunflowers. Phytopathology, 83, 1250-1252.

JACCARD, P. 1908. Nouvelles recherches sur la distribution florale. Bull. Soc. Vaud. Sci. Nat., 44, 223-270.

JACOBSOHN, R., GREENBERGER, A., KATAN, J., LEVI, M. AND ALON, H. 1980. Control of Egyptian broomrape (Orobanche aegyptiaca) and other weeds by means of solar heating of the soil by polyethylene mulching. Weed Sci., 28, 312-316.

JACOBSOHN, R., BOHLINGER, B., ELDAR, E. AND AGRAWAL, V. P. 1991. Crop host range of Orobanche species in an experimental field. In: Ransom, J. K., Musselman, L. J., Worsham, A. D. and Parker, C. (eds) Fifth International Symposium on Parasitic Weeds, Nairobi, Kenya, 24-30 June 1991, pp. 176-179.

JOEL, D. 1987. Detection and identification of Orobanche seeds using fluoresence microscopy. Seed Sci. Technol., 15, 119-124.

JOEL, D. 1988. Orobanche cumana, a new adventive weed in Israel. Phytoparasitica, 16, 375.

JOEL, D. AND JACOBSOHN, R. 1988. Weed leaves: the species of broomrape in our fields and their more important hosts. Hassadeh, 68, 2441-2442 (in Hebrew).

musselman, L. J. 1986. Taxonomy of Orobanche. In: Borg, S. J. (ed.) Proceedings of a Workshop on the Biology and Control of Orobanche, pp. 2-20 LH/VPO, Wageningen, The Netherlands.

MUSSElman, L. J. AND PARKeR, C. 1982. Preliminary host ranges of some strains of economically important broomrapes (Orobanche). Econ. Bot., 36, 270-273.

NESBITT, K. A., POTTS, B. M., VAILlANCOURT, R. E., WEST, A. K. AND REID, J. B. 1995. Partitioning and distribution of RAPD variation in a forest tree species, Eucalyptus globulus (Myrtaceae). Heredity, 74, 628-637.

PARAN, I., KESSELI, R. AND MICHELMORE, R. W. 1991. Identification of restriction fragment length polymorphism and random amplified polymorphic DNA markers linked to downy mildew resistance genes in lettuce using near-isogenic lines. Genome, 34, 1021-1027.

PARKER, C. 1994. The present state of the Orobanche problem. In: Borg, S. J. (ed.) Biology and Management of Orobanche. Proceedings of the Third International Workshop on Orobanche and Related Striga Research, pp. 17-26. Royal Tropical Institute, Amsterdam, The Netherlands.

PIETERSE, A. H. 1979. The broomrapes (Orobanchaceae): a review. Abstr. Trop. Agric., 5, 9-35.

SAS 1988. SAS User's Guide, Version 6. SAS Institute, Cary, NC.

VERKLEIJ, J. A. C. AND PIETERSE, A. H. 1994. Genetic variability of Orobanche (broomrape) and Striga (witchweed) in relation to host specificity. In: Borg, S. J. (ed.) Biology and Management of Orobanche. Proceedings of the Third International Workshop on Orobanche and Related Striga Research, pp. 67-79. Royal Tropical Institute, Amsterdam, The Netherlands.

VERKLEIJ, J. A. C., JANSSEN, J. AND PIETERSE, A. H. 1986. A preliminary study on isoenzymic variation in Orobanche crenata and Orobanche aegyptiaca from Syria. In: Borg, S. J. (ed.). Proceedings of a Workshop on the Biology and

(c) The Genetical Society of Great Britain, Heredity, 78, 68-74. 
Control of Orobanche, pp. 154-159 LH/VPO, Wageningen, The Netherlands.

VERKLEIJ, J. A. C., EGBERS, w. S. AND PIETERSE, A. H. 1989. Allozyme variations in populations of Orobanche crenata from Syria. In: Wegmann, K. and Musselman, L. J. (eds) Proceedings of the International Workshop on Orobanche Research, Obermarchtal, FRG, 19-22 August 1989, pp. 304-317.

VERKLEIJ, J. A. C., KOEVOETS, P., LOPEZ GRANADOS, F.,
EGBERS, W. S., GARCIA-TORRes, L. AND PIETERSE, A. H. 1991. Genetic variability in populations of Orobanche crenata from Spain. In: Ransom, J. K., Musselman, L. J., Worsham, A. D. and Parker, C. (eds) Fifth International Symposium on Parasitic Weeds, Nairobi, Kenya, 24-30 June 1991, pp. 462-469.

WACHIRA, F. N., WAUGH, R., HACKETT, C. A. AND POWELL, w. 1995. Detection of genetic diversity in tea (Camellia sinensis) using RAPD markers. Genome, 38, 201-210. 